\title{
Analysis on Development Process and General Situation of Modern Chinese Textile Technology
}

\author{
Wang Qin ${ }^{1} \&$ Yang Xiaoming ${ }^{2}$ \\ ${ }^{1}$ School of Textile, Donghua University, Shanghai, China \\ ${ }^{2}$ School of Arts, Donghua University, Shanghai, China \\ Correspondence: Wang Qin. E-mail: 721485442@qq.com
}

Received: June 16, $2021 \quad$ Accepted: July 3, $2021 \quad$ Online Published: August 30, 2021

doi:10.5539/ass.v17n9p44

URL: https://doi.org/10.5539/ass.v17n9p44

\begin{abstract}
In the early stage of China's modern capitalist industrialization, the national textile industry developed rapidly. The textile industry involved a wide range of industries. China's modern textile industry mainly includes filament, textile machinery manufacturing and wool textile industries in the development project of the textile industry in China's concession period, a number of textile industry central cities such as Shanghai, Tianjin, Qingdao, Wuhan, and Nantong have been formed.
\end{abstract}

Keywords: textile technology, modern times, times, machinery, social environment, development process

Undoubtedly, China is the world's largest manufacturer, consumer and exporter of textile products. The textile industry is not only a traditional pillar industry in the national economy, but also an important civilian production industry in China, and has strong international competitiveness.

\section{The Development History of China's Modern Textile Industry}

China's modern national textile industry is mainly dominated by Shanghai, Jiangsu, Wuhan and other coastal and riverside major cities and regions, and raw materials and machinery and equipment have to be imported from abroad. After the outbreak of the Anti-Japanese War, China's modern national textile industry suffered severely. After the War, China's national government took over 69 weaving factories invested by the Japanese capital during the wartime. Based on the integration of resources, the formation of the China Textile Industries Inc, had already posed the industry capacity at the leading position in the globe. China's textile industry at the time not only had the world's leading production techniques, but also pioneered in organizational management.

\subsection{Background of China's Modern Textile Industry}

Before the Opium War, China's self-sufficient feudal natural economy occupied a dominant position in the overall social economy; with the outbreak of the Opium War, Western capitalist countries continued to dump goods to China, and purchased domestic native products and industrial raw materials for self-sufficiency. The natural economic foundation of self-sufficiency was gradually destroyed. In the southeast trade areas, most of China's traditional handmade cotton textile industry was hit and in the challenge of bankruptcy. The textile intensive areas such as Songjiang, Taicang and other areas in the south of the Yangtze River were also severely challenged with a large number of foreign capital and yarns flooding into the city. Many cotton textile-based local workshops have closed down, leading to a reconstruction of social life.

\subsection{Birth of Chinese Modern Textile Industry}

Although the ancient Chinese was very developed in textile production technologies, ages within the government-run textile factory gathered a large amount of craftsmen, even as early as the Southern Song Dynasty when there emerged hydro large spinning wheel with a force textile machine prototype, because of the shackles of the traditional feudal hierarchy, and long-term self-sufficiency of the peasant economy dominated, resulting in closure technology and civil technology and insufficient supply of production factors as in the UK in the 17-18. Therefore textile technology was always stuck in handmade textiles stage, and did not like Western happen technological change leather, power contributed to the originator of the textile machine. Until foreign yarn, cotton goods after a lot of influx from abroad, this case condition gradually to change. 


\subsubsection{Generates Power Machine Chinese Textile Industry}

In 1872, the Chinese opened the prelude to setting up their own power machine textile factory. Chen Qiyuan returned home from overseas, to Nanhai, Guangdong and founded reeling following the Changlong Steam Engine Factory, and gradually adopted the French reeling car. In 1882, the nation's first capital created this textile machine factory in Shanghai Yongchang Machinery Plant was born in Shanghai, the main production of generic reeling machine. There were three main styles of silk reeling machine: French, Japanese and Italian. Cotton textile machinery was initially imported. In 1891, the first cotton spinning factory established by domestic private capital, Huaxin Textile New Bureau, was born in Shanghai. In 1896, Shanghai Yunzhang Hosiery Factory, the first knitting factory established by domestic private capital, was born. As of 1894, Chinese textile mill run by people in the modern sense, there were made more than 120 silk factories, over 30,000 silk machinery, and more than 30,000 specialized workers.

Till 1878 after the transformation of modern textile industry into Westernization, in the 1860s, some of the bureaucrats in power in the Qing Dynasty began to set up a batch of modern military industries in the name of a powerful country. In the late 1870s, the ruling bureaucracy began to focus on Western Europe's technology, which led to the introduction of related equipment and technical personnel, and modelled after modern factories in Western Europe to set up China's own textile mill. For example, in 1876, Zuo Zongtang, governor of Shaanxi and Gansu of the Qing Dynasty, allocated 200,000 taels to establish the Gansu Weaving Bureau, the first modern wool textile enterprise. Li Hongzhang successively founded the Shanghai Machine Weaving Company, the first modern cotton textile enterprise in China. In 1888, Zhang Zhidong established an official bureau of weaving in Hubei.

\subsubsection{Development of China's Modern Textile Industry}

The textile industry is the industry where national capital has entered the most. The productivity of China's textile industry in the pre-modern era has developed to a certain level, and the germination of capitalist employment-production relations has appeared. After entering modern times, Chinese textile weaving industry has been some development.

\subsection{Development Stages of China Modern Textile Industry}

\subsubsection{The Initial Development Stage of China's Textile Industry (1895-1913)}

China's cotton textile industry began to develop after the twenty-first year of Guangxu (1895). In just a few years, many spinning mills were established, which caused a sharp increase in cotton prices and labour prices. In addition, since the 25th year of Guangxu (1899), the surge of imports had depressed yarn prices and the cotton yarn market. As a result, the national cotton textile industry began to enter a low ebb in the 25th year of Guangxu (1899), and no new spinning mill was established in the 30th year of Guangxu (1904), and most of the original spinning mills were in difficulties. In the 30th year of Guangxu (1904), after the outbreak of the Russo-Japanese War, cotton cloth sold well, and yarn prices rebounded. In the 31st year of Guangxu (1905), the Chinese people launched a boycott of American goods, which greatly affected American cotton, which accounted for more than half of China's imported coarse cloth. As a result, the situation of the spinning mills has improved greatly. Under this stimulus, this period was the initial period of the modern national textile industry, and national capital set off an upsurge of investment in the construction of yarn. In the third year of Xuantong (1911), 11 new spinning mills were built nationwide. This year, the national total of 22 Chinese Cotton Mill (already destroyed or out except those sold to foreign investors), the total number of spindles reached 510, 008. From 1896 to 1913, the cotton textile industry started to come into scale. A major breakthrough within the years from 1896 to 1899 was that 7 private textile factories and 1 government-business joint spinning factory were built. By 1913, there were 23 domestic private cotton spinning mills with 484,000 spindles and 2,016 looms. As of 1913, the knitting workshop manual total of more than 10,000, mainly distributed in Jiangsu, Guangdong, lakes north, Liaoning, Zhejiang and other provinces. The silk weaving industry still mainly relies on hand-made old machines. In 1915, there were nearly 100 silk weaving factories nationwide.

\subsubsection{The Rapid Development Stage of China's Textile Industry (1914-1936)}

From 1914 to 1922, China's national textile industry entered a period of rapid development. At the same time, foreign textile industry made significant progress. From a historical perspective, since the outbreak of the First World War, the national textile industry development exhibition, with the changes in international and domestic social political environment, the general trend was on the rise of growth. During this period, power machine spinning began to gradually gain a dominant position in textile production.

Affected by the outbreak of the First World War, China's imports of foreign gauze sharp drop in the national 
capital of the textile industry was expanding rapidly. Yet at the same time, although the European industrial countries had no time for international communication, the national textile industry was still facing competition from Japan's investment and construction of factories in China. In 1914-1922, Japan established more than 30 textile factories in China. Only in 1914, Japan launched about 30 textile factories in China, with the capacity of more than 300,000 spindles and more than 3,500 looms; in 1922 this number surged to 1,080,000 spindles and 3969 looms. As of 1919, the Chinese people founded textile mills, the total number of workers reached about 358,000 , among whom 160,000 working in the production of cotton, 130,000 reeling, 30,000 knitting, and 38,000 in other lines of production.

From 1923 to 1931, due to the domestic warlords' melee and the return of foreign goods, the domestic textile industry fell into depression and its development pace slowed down. Since 1932, the sales of cotton textiles in China had gone from bad to worse. After 1933, four major spinning mills, namely Long Mao, Tong Chang, Yong $\mathrm{Yu}$, and Yu Zhong, have been forced to close down. Other textile companies were forced to suspend and reduce work.

Between 1932 and 1936, the domestic textile industry came into recovery. However, nature of private domestic capital was already greatly changed, reorganized as the state capital and comprador capital. The number of national textile enterprises forced to subletting, leasing, and auction or even close reached 35. By the end of June 1935, the country completely discontinued 24 national textile enterprises, reduced production of 14 factories. By 1936, before the introduction of the new cotton, there were still 23 enterprises in long-term production suspension. While still seeking growth in the cracks, the national capital textile industry developed rapidly during this period. Cotton spindles increased by 4.7 times; cloth machines increased by 11.7 times; wool spinning spindles increased by 4.9 times; the silk industry started to utilize mechanical reeling cars and electric power. Silk looms, hemp textile mills were added into production; printing and dyeing factories and dye industry were founded; imported textile machines were imitated.

\subsubsection{China's Textile Industry Slow Development Stage (1937 - 1949)}

From 1937 to 1949, China's national textile industry was affected by wars and drastic social changes. The industry experienced an arduous process from destruction, relocation, enemy occupation, and difficulties to adjustment, reception of enemy property, and restoration. The overall development speed was slow at this stage. At the end of the period, the total scale only recovered to the level before the Anti-Japanese War. With the outbreak of the Anti-Japanese War in July 1937, textile factories located along the coast and part of the interior were occupied by Japanese invading forces, and only a few textile factories moved inside. On the eve of the War of Resistance against Japan, there were more than 5 million spindles in China, of which 2.746 million spindles were owned by Chinese capital. During the Anti-Japanese War, due to transportation difficulties, only nine cotton mills in Henan and Hubei, and two wool mills were assisted by the Kuomintang government and moved to Sichuan and Shaanxi to resume work. There were about 70,000 spindles transformed from Vietnam, Myanmar transported, and from other self-made spinning method for inputting. In total, the five provinces of Sichuan, Shaanxi, Yunnan, Hunan and Guangxi had about 300,000 spindles of large and small models. In August 1945 after the war, the Japanese-owned textile mills all the Kuomintang government was received, Chinese textile workers industry will form three systems, namely bureaucratic capital, Chinese private capital, the British capital. There were National Textile equipment Spinning machine more than 400 million spindles loom 65000 units. The national capital cotton textile industry occupied half of the country, with 2.5 million spinning machines and 20,000 looms. With the industry capitalized, the largest national capital textile enterprises were developed including: Shanghai Textile public Division, Wing Textile Company, Cheng Fu textile companies, the newly founded Lai Sun Company, Qing Feng and other textile companies, Qingdao Huaxin Textile Company, Nantong Dasheng Textile company, Changzhou Dacheng Textile Company, etc.

In terms of raw materials, in 1948, due to the civil war, in addition to hemp production still outside, raw silk cut serious weight. Mainland China-made cotton, wool and other raw materials were shipped less than coastal factories, abandoned rotten in origin; since the outer exchange shortage, resulting in imports Raw materials have been drastically reduced, and a large number of textile mills have reduced production or even stopped working. From July 1948 to 1949 , rising prices led to part of the national capital textiles wavering, and some chose to withdraw money, and some chose to relocate to Hong Kong, Taiwan. As for Shanghai, there were only10 factories left, having 300,000 spindles of production output shipped to the Southern China. Most textile factories were still in place waiting for takeover by the state after the national liberation.

\section{China's Modern Textile Research and Development}

The development of the textile industry mainly depends on textile education and scientific research. In the 
modern times, the introduction of foreign advanced technology and equipment was the development of China's the first step on behalf of the power of the textile industry. Sufficient textile education, textile research and innovation, is always the solution for the further development of the industry.

\subsection{Lei Binglin's Contribution to Textile Research}

Lei Binglin was the famous textile engineering experts in our country, his "Big-Lei Binglin invention" and "two-hole yarn trumpet Law" in 1936 set the major breakthroughs in China textile industry development, with the former achievement receiving multiple. Inspired by Lei's large drafting, the inventions of "spring seat large drafting" and "spinning large drafting" came out one after another, which further promoted the development of modern textile scientific research in China. By probe analysis Lei Binglin and two inventions, Lei Binglin to develop the textile research and the start of the new big draft invention institutions show, leading to reflections on the development of China's modern textile research initiation.

\subsubsection{Binglin Lei Large Draft}

Binglin Lei Large drafting system referred to Reye's big draw is the big draw card's apron formula (Casablanca Draft) is developed on the basis. Card's apron-style big draft stationary cradle set by long-term use and the occurrence of loose lax, resulting in an uneven yarn and other issues, must be replaced apron, but at the same time increasing the cost of production, and the card's large Drafting is mainly aimed at Egyptian cotton and other long fibres, while China's spinning raw materials are mainly short fibres. Based on many years of experience , Lei believed that China's spinning mills should renovate large drafting machines based on the apron type , taking into account factors such as raw cotton and the ability of female workers, and adopting simple structure, firm parts, and convenient work are the most important . Lei carried out the transformation on the basis of the large drafting of the Kaspersky apron, maintaining the original three-row roller structure. The upper middle roller and the lower middle roller were respectively covered with the aprons to remove the large drafting of the Kaspersky. The fixed apron holder is changed to a movable two-position apron holder placed in the middle and lower rollers to control the four aprons. The protrusions at both ends of the apron holder are inserted into the special dragonfly head notches on both sides to prevent them from moving left and right. . After improvement, the function and efficiency of the Lei's large draft have evolved and improved compared with the Kasper's apron large draft. When the apron is drafted, for different fibres, the spring on the top of the stretcher can be slightly changed to increase the control of the apron over the fibre and ensure uniform yarn delivery. When the apron is used for a long time, the phenomenon of relaxation occurs. After that, the upper and lower stretchers are stuck in the same dragonfly head notch. Just simply adjust the position of the dragonfly head, you can conveniently control the movement of the upper and lower stretchers, so that the apron is re-tightened and the fibre is restored. The normal drafting ensures the quality of the yarn. Reye large draft pressure means a weight change before and direct automatic spring lever, and arranged opposite the pressing lever hammer apparatus, saving manufacturing costs, reduce body weight, reduce power consumption.

\subsubsection{Double Hole Trumpet Method}

Lei invented the double-guide horn device in Yongan's first design, which aims to enhance the compound effect of the roving machine and increase the output. The modification method is very simple. The single-hole yarn guide horn on the first roving machine is changed to double-hole, the distance between the front, middle and rear rollers is appropriately widened, and the front and rear weights are increased. A roving frame can produce double -fold yield, introducing a primary tampon, is increased to two, output doubled, less one half the spindle Wing a plant after reform, slubbing machine stops by about three tenths, and an increase of ten thousand spinning, and was transformed human labour, housing, power and materials, etc. can be reduced. $5 \mathrm{Wu}$ Guang conducted experiments in Yongan No. 3 Plant. The ordinary roving frame has 80 spindles and can only supply 2,000 spinning spindles. After modification, one roving primary spinning machine can supply 4,000 spinning spindles, which reduces half the cost of roving, get twice the result with half the effort. Addition Heyong Jiang and Chi training etc. double some research hole through the yarn guide horn method.

\subsection{Zou Spring and Spring Seat Pedestal Big Draft}

Zou Chunzuo, an engineer at the China National Textile and Construction Corporation at the time, invented the "Spring Block Double-Apron Large Draft" in 1947 and obtained a five-year patent granted by the Ministry of Economic Affairs. Large draft spring seat in the base of the card's apron drafting large transformation from the basis for the increase in the back roller set extending apron, whereby three rows of rollers have a roller and the back roller apron is provided, that The double apron is designed to improve the efficiency of the rear roller, further increase the drafting efficiency, and save production costs. Zou spring seat in China Textile Institute has published the twelfth annual meeting of the organization several advantages: drafting efficiency than ordinary 
single heavy apron to increase more than fifty times, one or two may be avoided by roving, direct access to use number roving or sliver into spun yarn; still used as roving II, Green roving increased, increasing plus yarn count ; skin removing roller racks, simple structure; Fourth, no iron device to reduce yarn breakage; V. The setting of the back apron further reduces the floating fibers and spun a more uniform yarn count.

Zou spring seat after spinning into the company, not only completed a large double apron drafting of the invention, also led to all kinds of big stretch comparative study. By observing various drafting mechanisms, he believes that although the structures are different, the principles are the same. They are all "roving through iron rods, aprons and top rollers to spin into spun yarn". Therefore, as long as the device is correct, the operation is flexible and the wiper "Sweep and clean" can ensure good drafting and reduce the difference between different institutions. Zou spring seat from the main pros and cons of two relatively drawing mechanism, after considering drafting a correction, whether easy to change, two for the organization is no easy wipe sweep. After comparing multiple drafting mechanisms, the conclusion drawn for the first point is that the one with heavy hammer is better than the one with spring, and the one with simple or strong structure is better than the one with complex or delicate structure. Regarding the second point, Zou Chunzuo believes that the small pile rollers on the aprons and the lower pile rollers on the middle and rear rollers are very important, and should be cleaned at any time. In addition to the large drafting mechanism, Zou Chunzuo is also responsible for the later blower and automatic cloth machine research.

In conclusion, in modern times, the development of my country's traditional hand-made textile industry has been impacted by Western power machinery textiles. In addition, due to the influence of war, politics, economy and other factors, the development of modern textile technology in my country has been slow and tortuous. Therefore, only active textile education and textile scientific research innovation can promote the development of China's textile industry.

\section{References}

"Modern Chinese Textile History" Editorial Committee. (1997). Modern Chinese Textile History (1840-1949) I. Beijing: China Textile Publishing House.

Chang, Y. P. (2005). Chinese textile industry analysis and development strategy. Beijing: China Textile Press.

Lei, B. L. (1947). Please order the national cotton mills to adopt yarn-guided double-hole horns and Lei Binglin's drafting machine to increase production efficiency. Textile Dyeing Engineering, 9(9), 70.

Lei, B. L. (1947). Responsibility of a technician. Textile Weekly, 8(1), 7.

Marx, K., \& Engels, F. (1992). The Communist Manifesto. Bantam Classics, 3(1).

Su, X., Deng, K. H., \& Yang, X. M. (2015). Analysis of Development of Spinning Research in Modern China Based on Lei Binglin and His Invention. Journal of Silk, 52(6).

Wu, G., \& Yin, J. (2013). Brand Influence China. I. Beijing: Beijing University of Technology Press.

Yan, Z. P. (2012). Selections of Statistical Data on Modern Chinese Economic History. Beijing: China Social Sciences Press.

\section{Copyrights}

Copyright for this article is retained by the author(s), with first publication rights granted to the journal.

This is an open-access article distributed under the terms and conditions of the Creative Commons Attribution license (http://creativecommons.org/licenses/by/4.0/). 